Research, part of a Special Feature on The influence of human demography and agriculture on natural systems in the Neotropics

\title{
Total Historical Land-Use Change in Eastern Bolivia: Who, Where, When, and How Much?
}

\author{
$\underline{\text { Timothy J. Killeen }}^{1}, \underline{\text { Anna Guerra }}^{2}, \underline{\text { Miki Calzada }}^{2}, \underline{\text { Lisette Correa }}^{2}$, Veronica Calderon $^{2}, \underline{\text { Liliana Soria }}^{2}$, \\ Belem Quezada $^{2}$, and Marc K. Steininger ${ }^{1}$
}

\begin{abstract}
We documented the history of land-use change and migration in eastern Bolivia in five temporal periods: pre-1976, 1976-1986, 1986-1991, 1991-2001, and 2001-2004. We included all landcover types located below the natural montane tree line $(\sim 3000 \mathrm{~m})$, including forest, savanna, scrubland, seasonal wetland, second-growth forest, pasture, and cropland. The rate of land-use change has increased from approximately $4.7 \times 10^{4} \mathrm{ha} / \mathrm{yr}$ in the $1960 \mathrm{~s}$ to $>2.9 \times 10^{5} \mathrm{ha} / \mathrm{yr}$ in the most recent period. Land-use change was quantified for 10 groups within which cultural traditions and production systems are shared, including three nonmechanized indigenous groups, four mechanized farming groups, two cattle ranching groups, and the forest products sector. Mechanized Cruceño farmers and Andean indigenous colonists were responsible for most land-use change in the 1960s and 1970s; deforestation by the latter group increased to twice that by all other groups during 1986-1991, declined in the 1990s, and then increased again in the most recent period. In the last 15 years, land-use change by agro-industrialists specializing in soybean has become important, and cattle ranching based on cultivated pastures has surpassed land use by all other groups. When the rates of change increased for the three indigenous nonmechanized groups, they tended to decrease for the four nonindigenous mechanized groups, and vice versa.
\end{abstract}

Key Words: deforestation; drivers; land-cover change; markets; migration; social sectors; tropics

\section{INTRODUCTION}

The Amazon is inhabited by various social groups that depend on its natural resources for their livelihoods. Many groups clear forest as part of the production system. An understanding of how these groups are integrated into local, national, and regional economies is essential to develop strategies to conserve natural habitat and ensure sustainability. Research has shown that deforestation is driven by multiple forces that can be identified by an analysis of spatial and temporal patterns linked to both cultural and economic phenomena (Bürgi et al. 2004). For example, forest resources are a mainstay of the local economy of traditional communities; nonetheless, most indigenous communities clear forest to provide food staples for their families. Large-scale deforestation is linked to migratory phenomena and the creation of road networks; in some instances colonies are planned by governments and international agencies, but more frequently, spontaneous settlements are created along highway corridors (Sierra 2000, Etter et al. 2005, Killeen et al. 2005, 2007).

In the Andean countries, most settlements produce rice and tropical fruits for highland urban centers; cattle production is important in Caquetá, Colombia, and Santa Cruz, Bolivia (Killeen 2007). The cultivation of coca for illicit cocaine is a driver of deforestation in Colombia, Peru, and Bolivia (United Nations Office on Drugs and Crime 2007; Bradley and Millington 2008). Soil depletion and weed infestation lead to abandonment, and the resulting anthropogenic landscapes are dominated by secondary forest (Brookfield and Padoch 1994, Steininger 2000).

In Brazil, land-use change is caused mainly by ranches that convert native vegetation to pasture to raise cattle for national markets (Margulis 2004, Fearnside 2005). Recently, the international 
demand for soybean has led to extensive conversion of the cerrado (a mosaic of savanna and forest) biome in Brazil, which is a biodiversity hot spot characterized by high levels of endemism (Myers et al. 2000, Machado et al. 2007). Most of the expansion in soybean has come from the conversion of pasture, but soybean is displacing the cattle industry into the Brazilian and Bolivian Amazon (Margulis 2004, Morton et al. 2006, Killeen et al. 2007).

The Andean and Brazilian economies have been separated by the geographic barrier of the Amazon wilderness. However, investments in infrastructure will soon integrate these regions; transcontinental highways will expand the agricultural frontier, and deforestation will be stimulated by technology transfer (Killeen 2007). Eastern Bolivia is a case that can be used to understand how cultural and technological interchange will influence land-use change in Andean countries following regional integration. Bolivia is already heavily influenced by Brazilian technology and has the second highest rate of deforestation in South America (Killeen et al. 2007). In addition, it is an ethnically diverse country that has indigenous peoples and longtime inhabitants of European descent, as well as more recent immigrants from Asia, North America, and Brazil. Settlements are characterized by differences in cultural tradition, access to technology, capital resources, and the security of land tenure.

Bolivia spans two major ecological transition zones. An altitudinal gradient constrains species distributions on the eastern slope of the Andes, whereas a latitudinal gradient characterized by decreased precipitation and increased seasonality broadly defines vegetation structure in the lowlands. Rain forest predominates in localized areas on the Andean piedmont (Killeen et al. 2007). Humid Amazonian species predominate on the northern plains; these transition into the seasonally dry forests of Chiquitania and eventually, the semi-arid woodlands of Gran Chaco to the south (Killeen et al. 2006). Geomorphology influences the distribution of habitat types across the latitudinal gradient, with seasonally flooded savanna wetland predominating on the alluvial plain of the Beni, and Cerrado savannas predominating on weathered upland soils or rocky landscapes on the Brazilian Shield (Fig. 1A). Differences in climate and soil fertility influence production systems and consequently, the composition of social groups that occupy the landscape.
We report patterns of land-use change in eastern Bolivia for 10 different social groups, covering half a century beginning with the Bolivian Revolution in the 1950s and the construction of the first modern highways that linked the lowlands with the Andean highlands in the 1960s. It encompasses periods when international commodity markets stimulated the cultivation of cotton and sugar (1970s) or led to the collapse of the country's mining industry (1980s), as well as public policies targeted at the eradication of illicit drugs and structural adjustments intended to promote private enterprise (1990s). Throughout this period, the road network has been expanded and improved, which has allowed the various social groups to expand their presence and consolidate their settlements while encroaching on lands that were previously dedicated to forest exploitation. Lowland Bolivia provides a distinctly interesting landscape with which to understand how different social groups react to the stimulus of international markets and public policies that are designed to stimulate economic growth and conserve forest (Pacheco 2006, Hecht 2005).

\section{METHODS}

\section{Image classification and GIS analysis}

Detailed descriptions of the satellite images, classification methodology, editing process, and validation procedures are reported by Killeen et al. (2005, 2007). In summary, we created a map of landcover change for eastern Bolivia below the tropical montane tree line (approximately $3000 \mathrm{~m}$ above sea level) covering the approximate period from 1991 to 2001 using orthorectified Landsat images (Tucker et al. 2004) and a nonsupervised classification to create approximately 125 classes that were grouped into eight strata: forest, native nonforest (i.e., cerrado savanna, Chaco woodland, savanna wetland), anthropogenic nonforest, second growth forest, water, hill-slope shadow, snow, and cloud, as well as the change among classes. Anthropogenic nonforest and second growth forest were grouped into one of four change categories, $i$. e., forest, cerrado, Chaco, or savanna wetland, and then further stratified into five temporal periods: pre-1976, 1976-1986, 1986-1991, 1991-2001, and 2001-2004. The stratification was based in part on a previous study covering the periods prior to 1991 (Steininger et al. 2001), and this was validated by comparison with the original imagery to correct classification and registration errors. Change from 
Fig. 1. (A) Land cover and historical land-cover change (LCC) in eastern Bolivia below the cloud forest treeline $(\sim 3000 \mathrm{~m})$, modified from Killeen et al. (2007). For LCC, the colored areas represents the outside edge of the deforestation front for agriculturalists in the most recent temporal period; the absence of LCC indicates the forest products sector and extensive cattle ranchers groups. (B) Geographic footprint of the major economic and social groups.

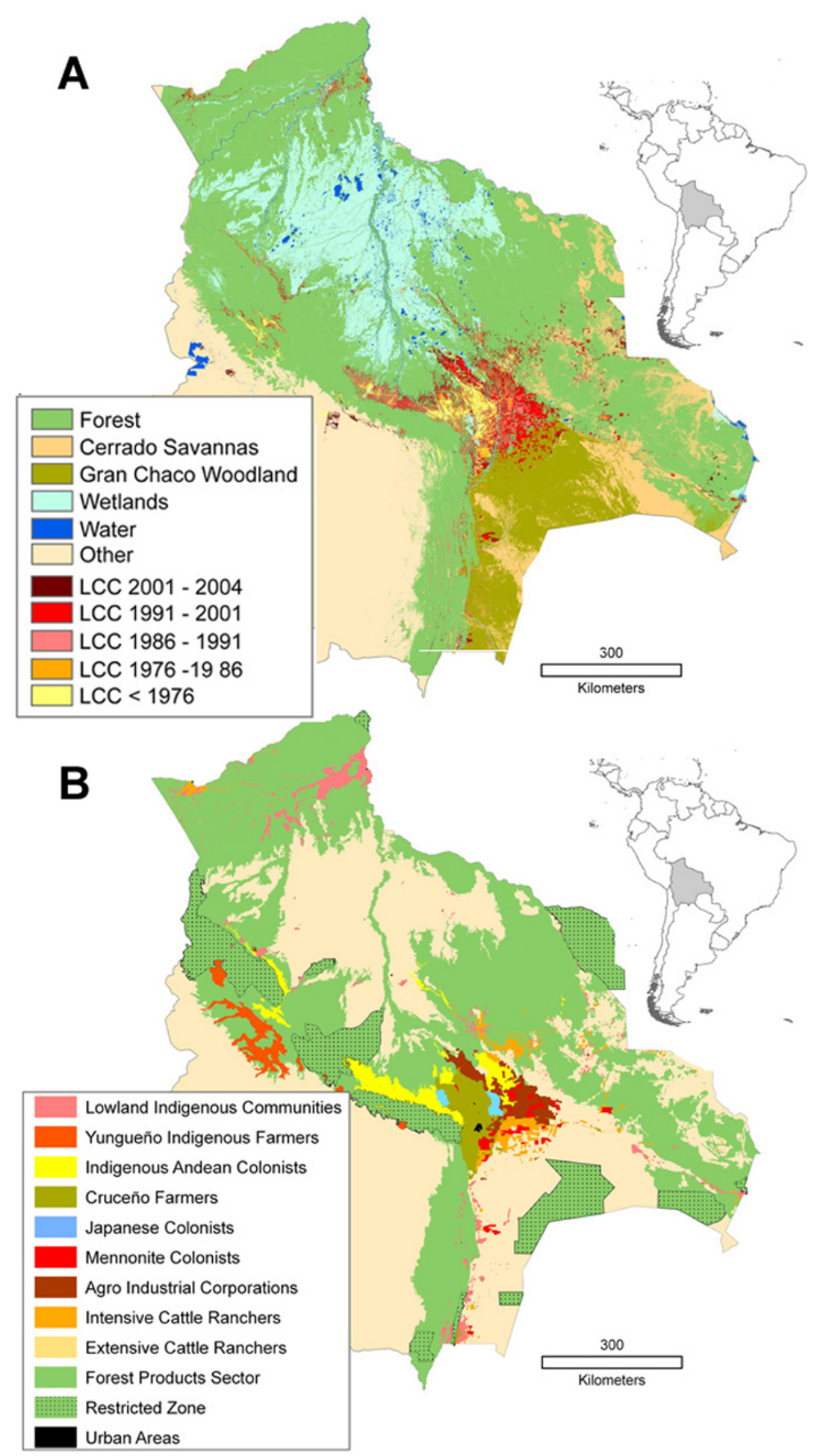


the most recent temporal period (2001-2004) was added to the map from a separate land-cover classification that was compiled from 14 Landsat scenes that contained $95 \%$ of all previous landcover change (Fig. 1A). The precision and accuracy of the land-cover map were evaluated by comparing the map with video images that were captured during validation flights conducted in late 2004 and early 2005. The probability of an error in classification for a pixel from inspected landscapes was relatively high, at $\sim 15 \%$, but because overestimates of deforestation cancel out underestimates, the accuracy of our summary results is relatively robust at $\sim 1 \%$ error (see Killeen et al. 2007).

The analysis of land-use change is based on an a priori classification of groups defined by differences in social organization, cultural history, technology, and degree of integration into the national economy (Table 1, Appendices 1 and 2). Each group has a known settlement history (Stearman 1985, Bender et al. 1987, Klein 1992, Amemiya 2004), and differences in production systems are reflected in deforestation patterns. The landscape footprint for each group was obtained by digitizing polygons at the outer edge of deforestation patches in the most recent Landsat image and includes recently cleared land, agricultural fields, and second growth forest, as well as natural habitat remnants situated among forest clearings (Appendices 1 and 2). Two groups were identified by the absence of land-use change and the presence of natural vegetation types that define their production system: the forest products sector and extensive cattle ranchers; essentially, these were defined by default by their lack of incorporation into other groups. No groups overlapped, and each landscape footprint comprised the total area occupied during the most recent temporal period. We present land-use change in absolute values, rather than as proportions, to avoid the artifact of changing baselines. The restricted-use zone includes only national protected areas that have complete protection, whereas multiple-use protected areas are included within the polygons assigned to the appropriate social group. Summary statistics were generated by overlaying the polygons with the multitemporal land-use change map in GIS. Finally, the land-use intensity was determined for six farm groups based on an evaluation of video images. The GIS polygons were used to stratify the flight transects from which 50-200 video frames were randomly selected for each group; land-use within each frame ( 7 ha) was summarized according to the percent cover of forest, native nonforest (e.g., Chaco, cerrado, or wetland), second growth forest, pasture, and cropland.

\section{RESULTS}

\section{Historical land-cover change}

Bolivia has experienced large amounts of landcover change over the past 50 years. Nonetheless, > $90 \%$ of the eastern part of the country remains as forest, wood land, grassland, or wetland (Fig. 1). Deforestation has been the predominant type of habitat conversion, but other biomes also have been affected. No single social or economic actor is responsible for a majority of habitat conversion (Table 2), but four categories can be recognized: nonmechanized or partially mechanized (indigenous) farming, highly mechanized (nonindigenous) farming, cattle ranching, and forest use and conservation. Nonmechanized or partially mechanized farming occupies approximately $4.6 \times 10^{6}$ ha and is responsible for $\sim 31 \%$ of converted habitat. This supra-group includes the categores of lowland indigenous communities, Yungueño indigenous farmers, and indigenous Andean colonists. Highly mechanized farming occupies approximately $3.16 \times$ $10^{6}$ ha and is responsible for $\sim 41 \%$ of converted habitat. This supra-group includes the categories of Cruceño farmers, Japanese colonists, Mennonite colonists, and agro-industrial corporations. Cattle ranching occupies $26.9 \times 10^{6}$ ha and is responsible for $\sim 20 \%$ of converted habitat. This supra-group includes the categories of intensive cattle ranchers, who clear forest for pasture establishment, and extensive cattle ranchers, who use native forage, but also convert native habitat to cultivated grasses. Forest use and conservation is the predominant activity on $43.8 \times 10^{6}$ ha, with $\sim 8.3 \%$ of the total converted habitat in both the restricted-use zone and the forest products sector, which includes private companies, indigenous reserves, and state lands.

On landscapes occupied by the first two supragroups, the amount of remnant forest was an unexpectedly large $3.1 \times 10^{6}$ ha, representing $\sim 7 \%$ of the total forest cover of eastern Bolivia. Approximately one-third of this was occupied by lowland indigenous communities (Fig. 2A). After removing this group, the number is still large, at $2.1 \times 10^{6}$ ha $(4.6 \%)$. The group with the least amount of forest remnant was Japanese colonists. 
Table 1. Criteria used to recognize and spatially define 10 social and economic actors, as well as the extent of restricted use and urban areas.

\begin{tabular}{lllll}
\hline \hline $\begin{array}{l}\text { Social and economic } \\
\text { group } \dagger\end{array}$ & Subgroup & Migration period & Technology & $\begin{array}{c}\text { Scale of land holding } \\
\text { (ha) } \ddagger\end{array}$
\end{tabular}

Nonmechanized indigenous agriculture

$\begin{array}{lccr}\begin{array}{l}\text { Lowland indigenous } \\ \text { communities }\end{array} & \text { before 1952 } & \text { Nonmechanized } & 1-5 \\ \begin{array}{l}\text { Yungueño indigenous } \\ \text { farmers }\end{array} & \text { before 1952 } & \text { Nonmechanized } & 10-25 \\ \begin{array}{l}\text { Indigenous Andean } \\ \text { colonists }\end{array} & \text { 1955-present } & \begin{array}{c}\text { Nonmechanized and } \\ \text { incipient }\end{array} & 25-50\end{array}$

Mechanized agriculture

$\begin{array}{lclc}\text { Cruceño farmers } & \text { before 1952 } & \text { Mechanized } & 100-1000 \\ \text { Japanese colonists } & 1954-1965 & \text { Mechanized } & 250-1000 \\ \text { Mennonite colonists } & \text { 1956-present } & \text { Mechanized } & 100-250 \\ \begin{array}{l}\text { Agro-industrial corpor- } \\ \text { ations }\end{array} & \text { 1986-present } & \text { Mechanized } & >1000\end{array}$

Cattle ranching

$\begin{array}{lccr}\begin{array}{l}\text { Extensive cattle } \\ \text { ranchers }\end{array} & \text { after } 1492 & \text { Native forage } & 500-10,000 \\ \begin{array}{l}\text { Intensive cattle } \\ \text { ranchers }\end{array} & \text { 1972-present } & \text { Cultivated pasture } & 100-10,000\end{array}$

Forest use and conservation

$\begin{array}{lccc}\text { Forest products sector } & \text { after } 1952 & \text { Timber and Brazil nut } & >10,000 \\ \text { Restricted use } & \text { after } 1990 & \text { Protected areas } & >100,000 \\ & \text { after } 1952 & \begin{array}{c}\text { Commerce and } \\ \text { industry }\end{array} & \end{array}$

$†$ See Appendices 1 and 2 for an overview and the spatial distribution of each group.

\#Information on the size of land holdings is based on anecdotal information obtained in field surveys conducted by Timothy J. Killeen as part of an unpublished consultancy conducted for the Bolivian government in 2005. 
Table 2. Summary of total historical land-cover change in eastern Bolivia stratified by four major vegetation types or biomes.

\begin{tabular}{lccc}
\hline \hline Land-cover type & $\begin{array}{c}\text { Remnant in } 2004 \\
\text { (ha) }\end{array}$ & Total land-cover change (ha) & Proportion converted (\%) \\
\hline Forest & $45,330,523$ & $4,618,317$ & 10.2 \\
Chaco woodland & $7,281,824$ & 494,565 & 6.8 \\
Cerrado savanna & $5,856,781$ & 348,831 & 6.02 \\
Llanos/wetlands & $13,384,889$ & 72,586 & 0.6 \\
Water & $1,048,471$ & & 7.6 \\
Total & $72,902,489$ & $5,534,299$ & \\
\hline
\end{tabular}

Note: See Appendices 1 and 2 for an overview and the spatial distribution of each subgroup.

\section{Temporal variation in land-cover change}

The dynamic of land-cover change in eastern Bolivia has changed over the last half-century (Figs. 2 and 3). Historically, settlement and deforestation was limited to landscapes near the city of Santa Cruz and the Yungas region of La Paz. Agricultural expansion led to the establishment of colonization zones in the Alto Beni, Chapare, and Yapacaní. Annual rates of change in the first temporal period (pre-1976) were calculated using a variable time period reflecting the approximate date when each group initiated settlement (Table 1). The three groups responsible for the most land-use change in this first temporal period were Cruceño farmers, Yungueño indigenous farmers, and Andean indigenous colonists (Fig. 3).

The total rate of change in the second temporal period (1976-1986) remained approximately equal to that in the previous temporal period, but declined for Cruceño farmers while increasing for Mennonite colonists in the mid-1970s (Bender et al. 1987). The largest increase came from Andean indigenous colonists (Fig. 3), who were settled in four separate colonization zones by 1968 (Table 3). The newest colony, San Julian, was laid out on a grid, with communities located at intersections of secondary roads; the distinctive radial deforestation pattern reflects the land titling system within this planned colonization zone (Appendices 1 and 2). Settlement in other spontaneous colonization zones occurred along primary and secondary roads, forming a fishbone pattern characteristic of colonization projects throughout the Amazon (Skole and Tucker 1993).

The third temporal period (1986-1991) showed an increase in land-use change for all groups, with Andean indigenous colonists showing the largest increase (Fig. 3). Agro-industrial corporations became established on the alluvial plain east of the Río Grande River (Appendices 1 and 2). At this point, habitat conversion for mechanized farming approximately equaled that for nonmechanized farming (Fig. 3).

The trend in habitat conversion changed radically in the fourth temporal period (1991-2001). Agroindustrial corporations expanded exponentially, whereas Andean indigenous colonist showed a sharp decline (Fig. 4). Intensive cattle ranchers experienced a 10-fold increase in the clearing of Chiquitania cerrado and Gran Chaco woodlands (Fig. 2C). Mennonite farmers increased their annual rate of land-cover change, whereas Japanese colonists, Cruceño farmers, and lowland indigenous communities all showed decreases. 
Fig. 2. (A) Remnant habitat and total land-cover change (1976-2004) for eight groups that depend on habitat conversion as part of the production strategy. (B) Cumulative land-cover change according to production system and access to technology. Nonmechanized indigenous Andean colonists have been acquiring mechanized technology in selected colonization zones (see Table 3), and both cattle ranching groups establish pastures using a variety of technologies ranging from manual labor with chain saws to the use of bulldozers and chains. (C) Cumulative land-cover change over five temporal periods for both intensive and extensive cattle ranchers. Habitat conversion has increased over time while also expanding to include a broader range of vegetation types.

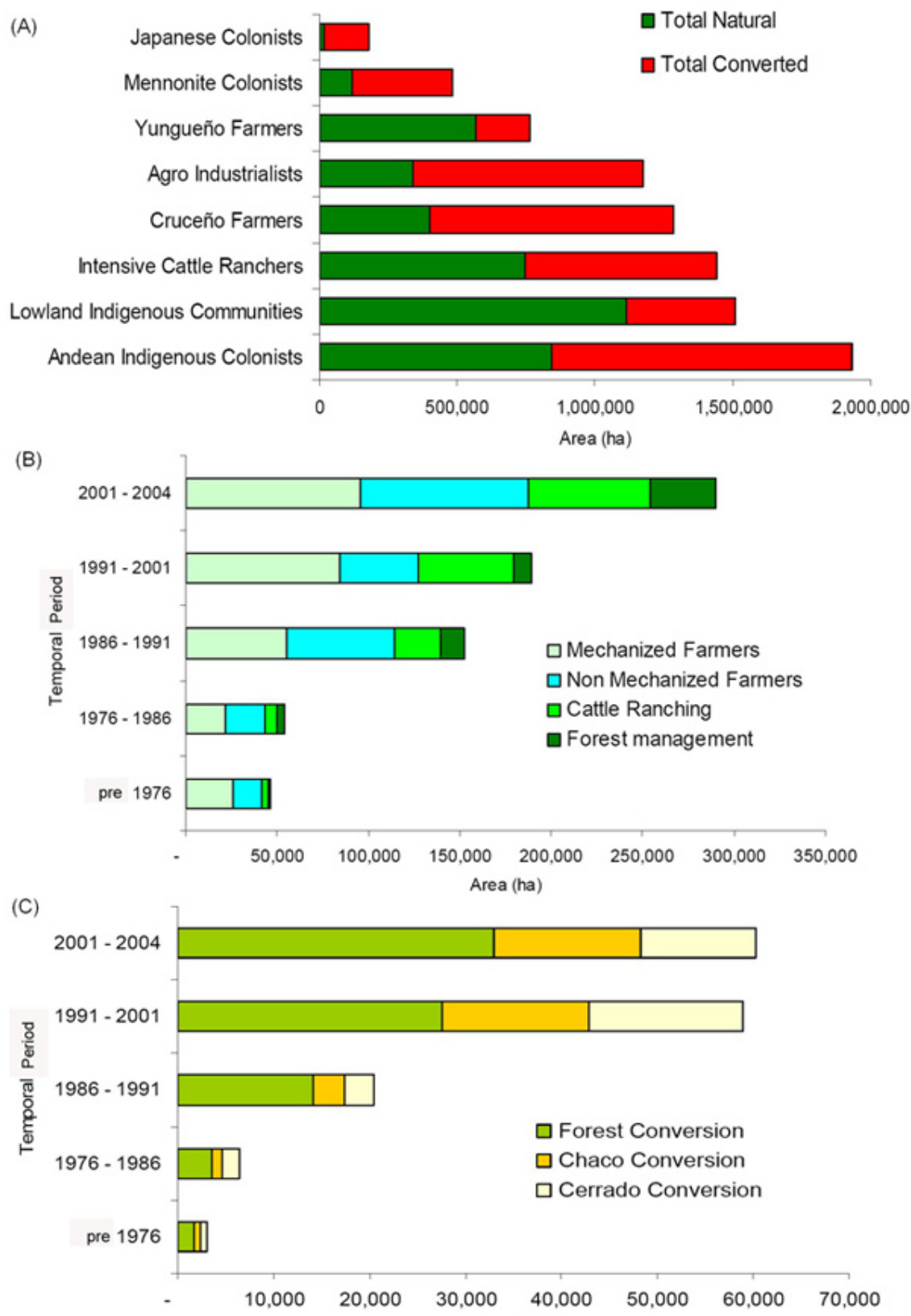


Fig. 3. The temporal variation in land-cover change among social and economic groups in eastern Bolivia reflects differences in global markets, the national economy, government policies, and migratory phenomena characteristic of individual groups.

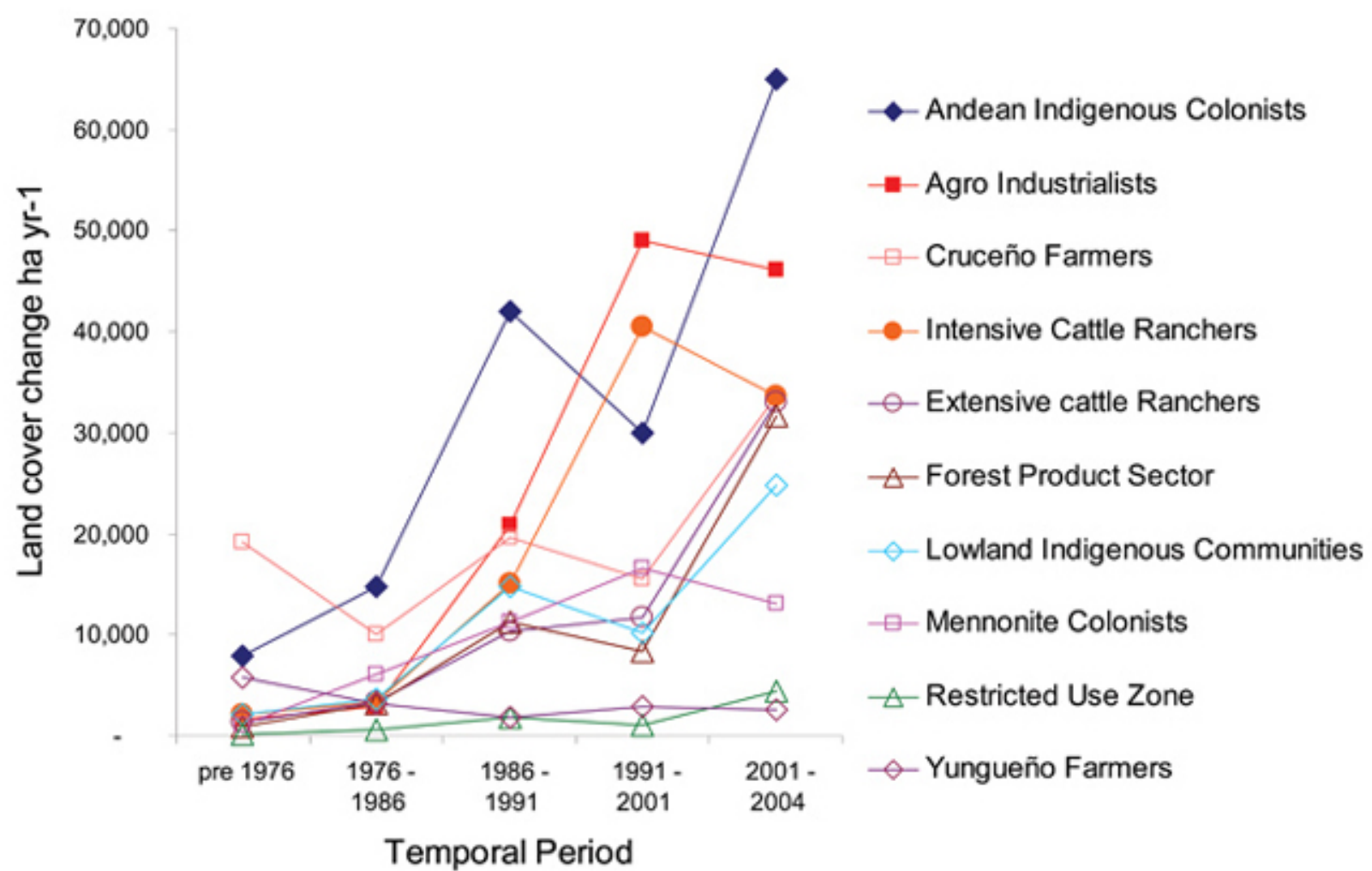

The fifth and most recent temporal period (20012004) demonstrates the unpredictable nature of the phenomena that drive land-cover change in Bolivia. The growth in deforestation rates leveled off for agro-industrial corporations and intensive cattle ranchers, but increased for Cruceño farmers and extensive cattle ranchers. The previous decline for indigenous groups reversed, rebounding to all-time highs for lowland indigenous communities and Andean indigenous colonists (Fig. 3).

\section{Land-use intensity}

The term land-use intensity refers to the proportion of land dedicated to crop, pasture, second-growth forest, and forest: cultivation is more intensive than pasture, and pasture is more intensive than second- growth forest. The two indigenous groups included in the video survey have a similar intensity of land use following deforestation (Fig. 5); the small amount of land dedicated to crops by the Andean indigenous colonists is due in part to climatic constraints in colonization zones where the annual rainfall exceeds $3000 \mathrm{~mm}$ and long fallows are necessary to maintain productivity. Fallow includes pasture, as well as second-growth forest, because indigenous groups tend to raise pigs and chickens, rather than cattle. The San Julian colony has less land in fallow compared to other colonization zones (Fig. 4), reflecting the more amenable climate (e.g., mean annual rainfall of 1500-2000 mm), fertile alluvial soils of the Río Grande plain, and an incipient process of mechanization (Cochrane et al. 2007). 
Table 3. Regional variation in the environment and production systems in four different regions settled by Andean indigenous colonists.

\begin{tabular}{llcccc}
\hline \hline Colonization region & Physiography & $\begin{array}{c}\text { Date of first } \\
\text { settlement }\end{array}$ & Area (ha) & $\begin{array}{c}\text { Mean annual } \\
\text { precipitation (mm) }\end{array}$ & Major crops \\
\hline $\begin{array}{l}\text { Alto Beni and } \\
\text { Yacumo }\end{array}$ & $\begin{array}{l}\text { Syncline valley and } \\
\text { foothills }\end{array}$ & 1960 & 287,172 & 2000 & $\begin{array}{c}\text { Rice, coffee, } \\
\text { cacao, fruits }\end{array}$ \\
$\begin{array}{l}\text { Chapare } \\
\text { Yapacaní } \dagger \text { and Santa }\end{array}$ & Piedmont and foothills & 1960 & 623,906 & $4000-6000$ & Coca \\
Rosa & 1960 & 475,002 & $2000-4000$ & Rice, soybean \\
San Julian $\dagger$ & $\begin{array}{l}\text { Alluvial plain of the } \\
\text { Río Grande }\end{array}$ & 1968 & 460,915 & $1500-2500$ & $\begin{array}{c}\text { Maize, sunflower, } \\
\text { soybean }\end{array}$ \\
\hline
\end{tabular}

Note: See Appendices 1 and 2 for an overview and the spatial distribution of each subgroup.

$\dagger$ The colonization zone has incipient mechanization.

Mennonite colonists and agro-industrial corporations have the most intensive land use, with $>60 \%$ of cleared land dedicated to annual crops and low levels of second growth. Japanese colonists maintain approximately equal proportions of land under cultivation and pasture, a level of land use that is less intensive than that of Cruceño farmers (Fig. 5).

The moderately high levels of remnant forest vegetation documented for farming groups is deceptive; these groups are expanding their landuse footprint, and forest remnants are exterminated over time. The second-growth forest observed for agro-industrial corporations is an artifact caused by a single abandoned farm. Intensive cattle ranchers maintain slightly less than $50 \%$ of the landscape as forest, even in relatively well-established settlement regions; however, this group has very little land in second-growth fallow because most cleared land is maintained as perennial pasture. The importance of livestock for mechanized farmers is evidenced by the relatively high levels of pasture for all four groups (Fig. 5).

\section{DISCUSSION}

The scientific literature and the popular press have published thousands of reports on the dimensions, extent, and impacts of deforestation in the Amazon. Understanding the social and economic actors involved in the expansion of the agricultural frontier is essential for developing policies to slow deforestation and conserve natural ecosystems.

\section{Indigenous farmers}

Subsistence agriculture continues to play an important role in the dynamic of deforestation in Bolivia. The level of habitat conversion associated with lowland indigenous communities is small, but has expanded over time. Our results show that if income from forest resources is restricted, deforestation will increase as agricultural production replaces forest resources. The increase in deforestation in the third temporal period (19861991) coincided with the collapse of the rubber trade when Brazil ended rubber subsidies in the 1980s. Instead of keeping workers in the forest for 12 months each year, companies contracted seasonal labor for the Brazil nut harvest. Employees migrated from remote stations to villages, and the increase in deforestation in northern Bolivia was related to an 
Fig. 4. Land use and land-use intensity for three regions occupied by Andean indigenous colonists. Differences in land-use intensity are related to climate, soils, and cropping system (see Table 3).

\section{Andean Indigenous Colonists - Chapare}

Forest

Non Forest

Water

Converted
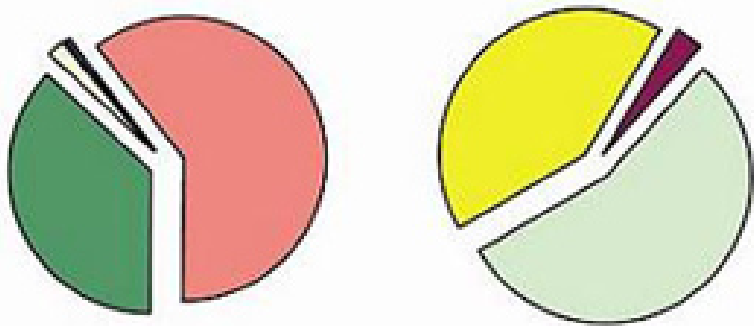

$\square$ Second Growth

$\square$ Crops

Pasture

\section{Andean Indigenous Colonists - Yapacaní}
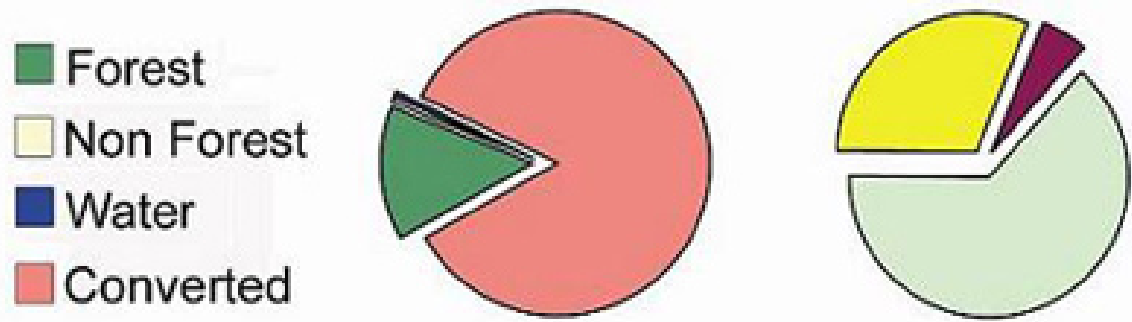

Second Growth

Crops

Pasture

\section{Andean Indigenous Colonists - San Julian}

\section{Forest \\ $\square$ Non Forest \\ Water \\ $\square$ Converted}
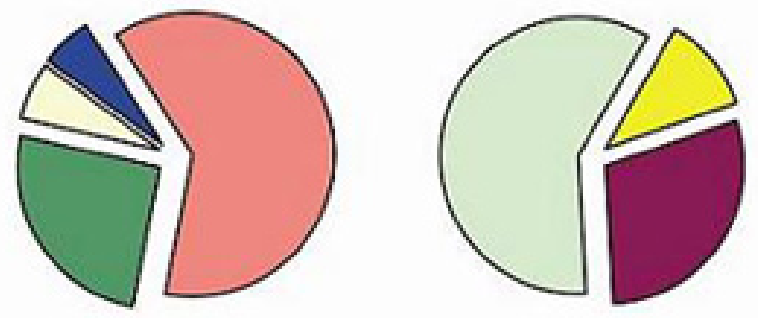

Second Growth

Crops

Pasture

increase in subsistence farming near communities (Fig. 6).

Andean indigenous colonists initiate their settlements as subsistence farmers, but production quickly becomes focused on national markets. Wildlife resources are exhausted and timber is exterminated over the short term, obligating settlers to adopt intensive agricultural systems; cultural links to urban centers facilitate the settlers' access to national markets (Stearman 1985). Global markets and international policy had a profound impact on the deforestation rates of Andean indigenous farmers. Coca has been legally 
Fig. 5. Land-use intensity for six social and economic groups as determined from a random sample of video images captured during a validation flight. The land-use categories in the right columns are nested within the converted category in the left column.

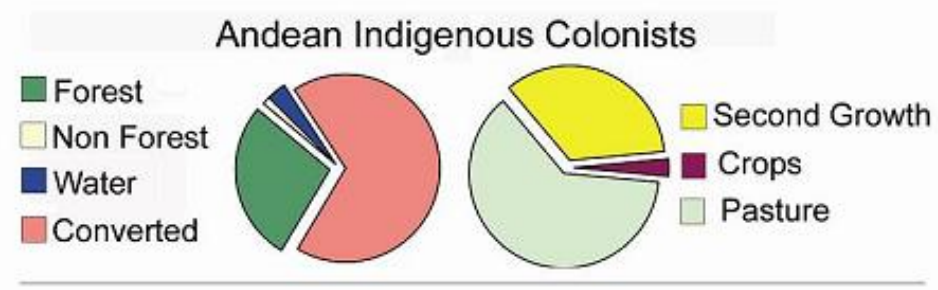

\section{Lowland Indigenous Farmers}
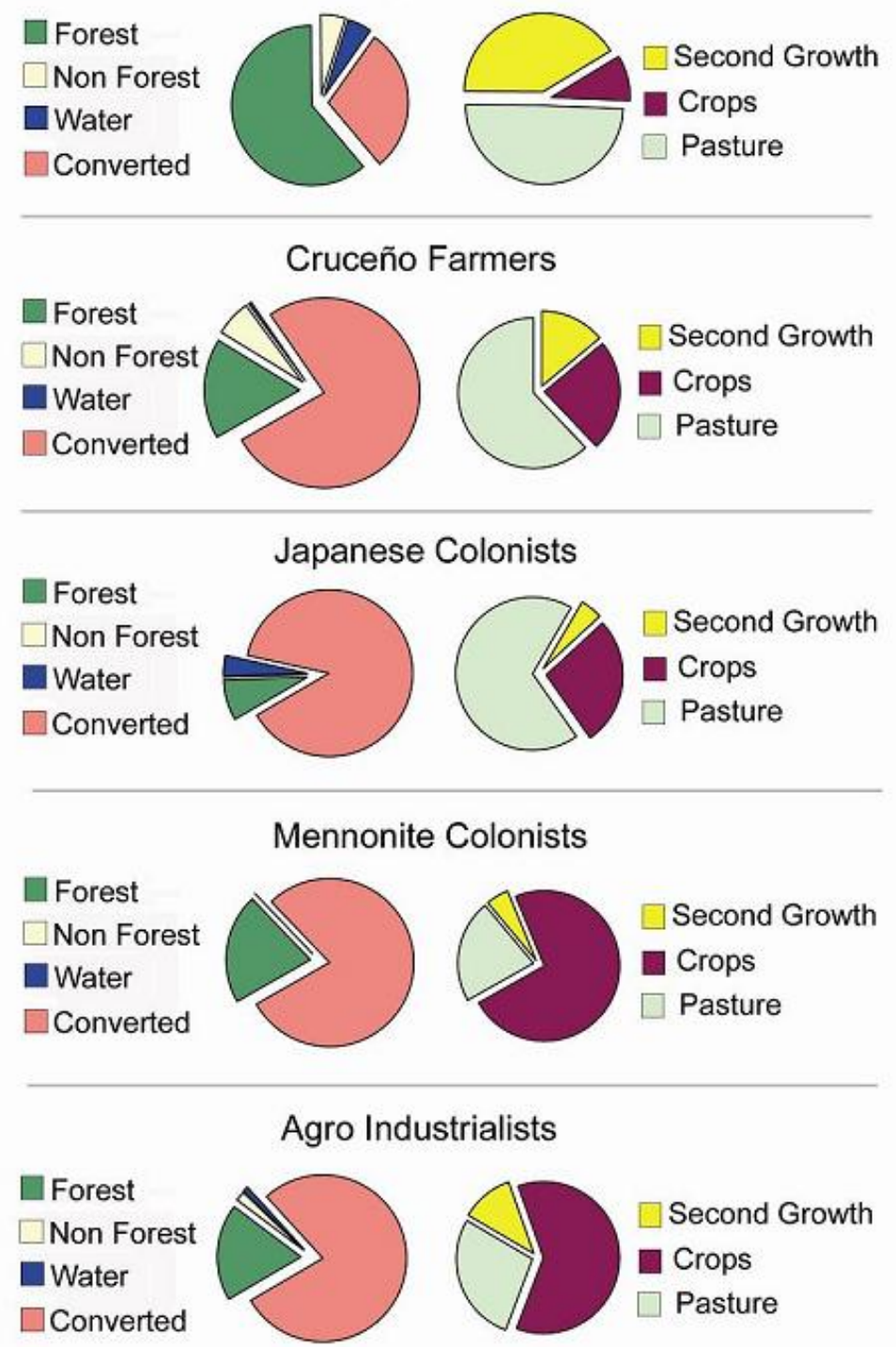
Fig. 6. Deforestation rates for 15 municipalities in northern Bolivia (see inset). The peak in deforestation between 1986 and 1992 occurred after Brazil ended subsidies to rubber collectors. The value for the most recent period is an underestimate because of incomplete coverage for this period (modified from Killeen et al. 2007).

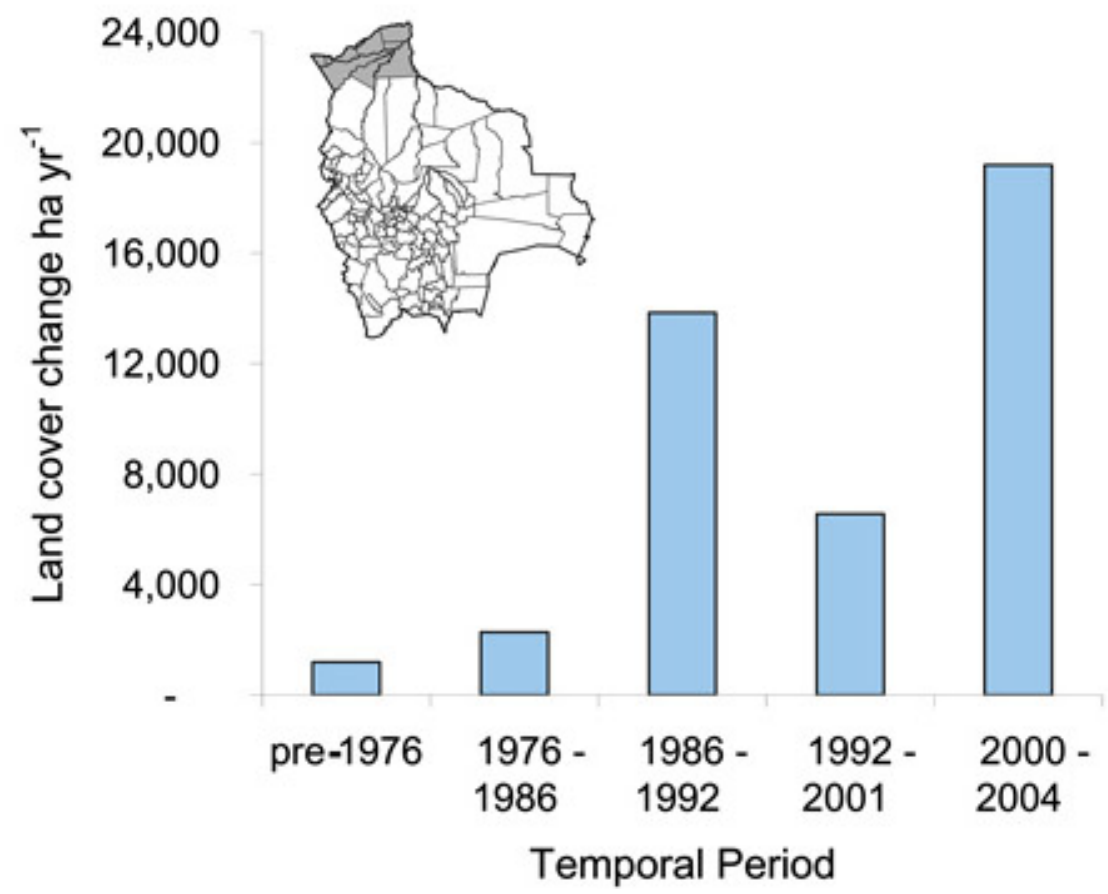

cultivated in Bolivia for millennia by Yungueño indigenous farmers, but once cocaine consumption increased in the $1970 \mathrm{~s}$, illicit cultivation expanded to the Chapare colonization zone. Deforestation dramatically increased in the mid-1980s following the collapse of international tin prices and the termination of $\sim 2.0 \times 10^{4}$ miners by the national mining company (Klein 1992). The subsequent increase in migration coincided with a period of weak governance that contributed to the boom in coca cultivation. In the 1990s, Bolivian governments implemented an aggressive interdiction policy with international assistance (United Nations Office on Drugs and Crime 2007), and deforestation associated with Andean indigenous colonists decreased by almost one-third; however, the downward trend was reversed in the last temporal period as coca policy changed from eradication in the 1990s to tolerance in 2002-2005, and more recently, permissiveness post 2005 (Fig. 3).
Despite its importance, it would be inaccurate to attribute most of the deforestation from Andean indigenous colonists to the cultivation of illicit coca. The Chapare colonization zone is only one of four major colonization zones: the Yapacaní colonies specialize in citrus and rice; San Julian is a major source of maize; and the Alto Beni has a diversified agricultural system (Table 3). Slash-and-burn agriculture is the major production system in all of these regions, but established settlers invest in intensive cropping systems and acquire trucks, tractors, harvesting machines, and other implements. Evidence of mechanization can be seen in San Julian, where older settlements near the major highway show less secondary growth than do younger settlements that are situated further to the northwest (Appendices 1 and 2).

The increase in land-use change in the last temporal period for Andean indigenous colonists and lowland indigenous communities demonstrates the impact 
of public policy on land-cover change. The dissatisfaction of the Bolivian populace with the economic reforms of the 1990s led to a fluctuation in the political dynamic, and indigenous groups have been newly empowered in the competition for land and forest resources (Movimiento al Socialismo 2007). In northern Bolivia, the former employees of rubber and Brazil nut concessionaires are being granted titles to land that was previously managed by their former employers; these settlers are supplementing Brazil nut harvest with subsistence agriculture (Ruiz 2005). Andean indigenous colonists are occupying state lands or properties with unclear titles, as well as invading forest reserves and protected areas, whereas the Bolivian government is advocating a return to planned settlement schemes (Constituyente Soberana 2006).

\section{The cattle sector}

Lowland Bolivia has a long tradition of cattle ranching that has evolved over the last three decades as new technologies increase productivity and profitability. The shift from native forage to cultivated grasses began as a response to the scarcity of fodder during the dry season, and the British Mission in Tropical Agriculture introduced many of the most successful cultivated grasses in the 1970s (Paterson 1984). Ironically, one of the stated goals of this Mission was to reduce deforestation by increasing productivity on previously deforested lands. Increased profitability led to the expansion of intensive cattle ranching, and pasture establishment showed near-exponential growth in the 1980s and 1990s (Figs. 2B and 3) and eventually impacted traditional grazing lands (Fig. 2C).

Extensive cattle ranchers remain the largest sector within the cattle industry (Table 4), but their role within the industry has shifted to providing calves and yearlings to intensive cattle ranchers and mechanized farming groups, which maintain part of their land holdings as pasture (Fig. 5). Deforestation by intensive cattle ranchers has been influenced by the ongoing reform of land tenure. During the 1970 s and $1980 \mathrm{~s}$, large tracts of state land were distributed to individuals who had political influence; subsequent governments attempted to recover land using provisions of the Land Reform laws of 1997 and 2007. Land titles revert to the state if the holder can not demonstrate that the property fulfills an "economic and social function" (Instituto Nacional de Reforma Agraria 2007a). Many of the lands that have questionable titles are situated on forest landscapes, and most land holders choose to present legal briefs based on the intensive cattle ranching model. The area allowed to each land holder under this model is based on a formula that includes the number of cattle and the area of cultivated pasture; consequently, pasture establishment is driven partly by land holders protecting their holdings from reversion to the state.

\section{Mechanized agriculture}

The most intensive land use in Bolivia occurs on mechanized farms on the alluvial soils of the Río Grande plain. Approximately $42 \%$ of total deforestation has occurred in this area. The four mechanized farming groups show different patterns of land use that reflect access to technology, capital, cultural traditions, and political influence.

The Cruceño farmer group includes small, medium, and large properties; individual producers specialize in sugarcane, cotton, rice, soybean, beef, dairy, poultry, or some combination of these. All are highly mechanized and consume fuel, seeds, and chemicals; import machinery; and invest in infrastructure. Some farmers used disk harrows on wet soils in the 1970s, causing subsoil compaction; degraded lands were converted to pasture and are one explanation for the high cover of pasture (Fig. 5). Land change in the last temporal period occurred near the Río Grande floodplain, an area at risk from inundation. The remaining forest landscape $(\sim 30 \%)$ is situated on the rolling hills near the Andes and is suitable only for pasture and forest management (Prefectura del Departamento y Consorcio IP-CESKWC 1996).

Japanese colonists are medium-scale farmers who arrived in the 1950s and occupied the lands with the best soil and climatic conditions. Their close-knit social organization allowed them to obtain economies of scale by forming cooperatives. Technical support from the Japanese government has played a role in introducing new crops and technology. Japanese colonists have deforested a higher percentage of their land holdings than has any other group; their land use includes the rotation of crop land and pasture (Amemiya 2004).

Mennonites are accomplished farmers who have an extensive knowledge of cropping systems; however, their cultural tradition leads them to 
Table 4. Characteristics of extensive cattle ranches in three geographical regions of eastern Bolivia.

\begin{tabular}{|c|c|c|c|c|c|}
\hline Region & Ecosystem & Forage & Area (ha) & $\begin{array}{c}\text { Mean annual } \\
\text { precipitation }(\mathrm{mm})\end{array}$ & $\begin{array}{l}\text { Stocking rate } \\
\text { (animals/ha) }\end{array}$ \\
\hline Llanos de Moxos & Inundated savanna & $\begin{array}{l}\text { Flooded grass- } \\
\text { land }\end{array}$ & $10,258,396$ & $1500-2000$ & 0.3 \\
\hline Chiquitania & Cerrado & $\begin{array}{l}\text { Upland grassl- } \\
\text { and }\end{array}$ & $2,724,978$ & $1000-1500$ & 0.2 \\
\hline Gran Chaco & Gran Chaco & Thorn scrub & $1,827,532$ & $500-1000$ & 0.1 \\
\hline
\end{tabular}

Note: Stocking rates were obtained from ranchers. See Appendices 1 and 2 for an overview and the spatial distribution of each subgroup.

idiosyncratically limit the use of technology (Bender et al. 1987). In Bolivia, they eschew the ownership of cars and trucks, but will rent these services as needed; they own tractors, but use steel wheels, rather than rubber tires, even though this leads to soil compaction. They use genetically modified organisms and chemical inputs, but have been slow to adopt minimum tillage. Mennonite colonists have high combined rates of land-cover change and land-use intensity, but have settled in areas that have sandy soils and are exposed to periodic drought (Appendices 1 and 2).

The expansion of agro-industrial corporations started with a World Bank project to expand agricultural production to the eastern sector of the Río Grande plain. The Eastern Lowlands Project (World Bank 1997) included investments in silos, processing facilities, highways, and technical assistance, as well as land-use planning and biodiversity conservation (Prefectura del Departamento y Consorcio IP-CES-KWC 1996). Santa Cruz is situated across a pronounced precipitation gradient, with mean annual precipitation ranging from 3000 to $800 \mathrm{~mm}$ across a northwest-southeast transect of $150 \mathrm{~km}$ (Cochrane et al. 2007). The Eastern Lowlands Project Area was situated near the southern end of this gradient; within the first decade of the project, agro-industrial corporations experienced crop failures due to drought. Subsequent investments flowed to more humid landscapes situated west of the Río Grande and north of the lands occupied by Cruceño farmers (Appendices 1 and 2). Although this area is at less risk from drought, it has greater risk of flooding because it is situated in a delta-like landscape where three rivers, i.e., the Grande, Piraí, and Yapacaní, have meandered in recent history and an upsurge in wetland conversion in the last temporal period (1224 to $14,500 \mathrm{ha} / \mathrm{yr}$ ) can be attributed to settlement on this landscape.

Periodic booms fueled by international markets have played an important role in the expansion of agro-industrial corporations because producers respond to short-term opportunities by clearing new land. The existence of the agricultural frontier has impeded investment that might lead to higher levels of productivity. Investors have a number of economic incentives to clear land on the frontier to expand production: land is inexpensive in remote areas; nutrients stored in biomass ensure good harvests in the initial years of the investment cycle; and economies of scale can be easily obtained in a single land purchase, avoiding the need to consolidate small holdings.

Policy incentives could promote the use of technology to increase crop yields in older fields as an alternative to habitat conversion. Santa Cruz is situated over a large aquifer that could be exploited indefinitely because it is recharged by precipitation 
and high-volume Andean rivers (Cochrane et al. 2007). However, irrigation requires a capital investment that has a less attractive rate of return compared to that of buying land, clearing forest, and expanding production. Similarly, chemical fertilizers are not used in Bolivia because of the high cost; there are no fertilizer factories, despite the country's abundant natural gas reserves, which are the primary feedstock for nitrogenous fertilizers. Economic models show that if irrigation and fertilizers were used at optimum levels, crop yields could be doubled while eliminating climate risk (Cochrane et al. 2007).

\section{Forest management and conservation}

The forest products sector showed an idiosyncratic pattern of deforestation over the five temporal periods. Initial rates of deforestation were low, but increased with time, with peaks in the third and fifth temporal periods (Fig. 3). These moderately large deforestation rates are the consequence of the large total area and numerous scattered patches of deforestation that sum to a large number in absolute terms, but are small in relative terms (Table 2). The forest products sector has a long history of sustainable exploitation that is rooted in the two rubber booms of the late 19th and 20th centuries and the ongoing exploitation of Brazil nuts. However, it also has a history of short-term exploitation and the exhaustion of renewable resources, as exemplified by the cases of palm hearts (PeñaClaros and Zuidema 2000) and mahogany (Kometter et al. 2004).

In the 1970s and 1980s, the state granted logging contracts for $40-\mathrm{yr}$ periods to companies that exploited mahogany; timber royalties were based on the volume of wood harvested. This model collapsed in the late 1990s with the commercial extinction of mahogany and was replaced by a system based on multiple species exploitation, reduced-impact logging, and natural forest regeneration (Putz et al. 2004). Under the new scheme, concessionaires are required to implement management plans with rotational harvests spanning $30 \mathrm{yr}$, and royalties are based on the area of the concession. Companies had to rationalize the demand for timber with their ability to pay a tax based on spatial area; consequently, large blocks of forest were returned to the state. Under the new model, concessions were made available to communities via cooperatives (Asociaciones
Sociales del Lugar), and lowland indigenous communities were granted reserves (Tierras Comunitarias de Orígen, TCOs; Instituto Nacional de Reforma Agraria 2007b).

These groups currently occupy, manage, or have claims to approximately $50 \%$ of the area defined as the forest products sector (Fig. 7) and are competing for the remainder of the forest, which is nominally held by the state. In the northern part of the country, companies that dominated the Brazil nut industry for decades are defending their concessions, arguing that they have managed the forest responsibly, but now face competition from former employees who are demanding titles to forest lands (Ruiz 2005). The forest landscape in the rest of Bolivia eventually will be divided among companies, cooperatives, and indigenous communities or will be occupied by one of the farming or ranching groups.

Forest vegetation is part of the landscape in the settlement areas of all groups; in the case of Mennonite and Japanese colonists and agroindustrial corporations, the persistence of forest is a temporal phenomenon and is likely to be lost over time. Even forest remnants that are left as windbreaks on industrial farms will be degraded due because of the well-known edge effect (Laurance et al. 2002). In contrast, the forest fragments that are associated with intensive and extensive cattle ranchers are more likely to persist over the long term. Ranchers tend to consider forest remnants as capital assets and view their properties as dualpurpose production estates.

Indigenous groups maintain a large portion of the landscape as either forest or secondary forest fallow (Fig. 4). Lowland indigenous communities are usually located near their own forest reserves (TCOs) and their farming activities complement forest resources. In contrast, Andean indigenous colonists have a much greater impact on the forest, and the fate of native forest remnants within their landscape footprint is similar to that of mechanized groups, although the abundance of secondary forest makes these landscapes more amenable for biodiversity conservation.

The absolute low rate of change reported for restricted zones is deceptive because these polygons exclude parts of protected areas that are occupied by Andean indigenous colonists and are included in the statistics for that group. A separate analysis that evaluated protected areas showed that deforestation 
Fig. 7. The distribution of forest-use rights within the forest products sector. Private companies and cooperatives are pooled; indigenous communities include both lands legally ceded to them and outstanding demands; and multiple-use protected areas are part of the national protected area system. Lands that have undocumented tenure often have multiple claims for competing uses.

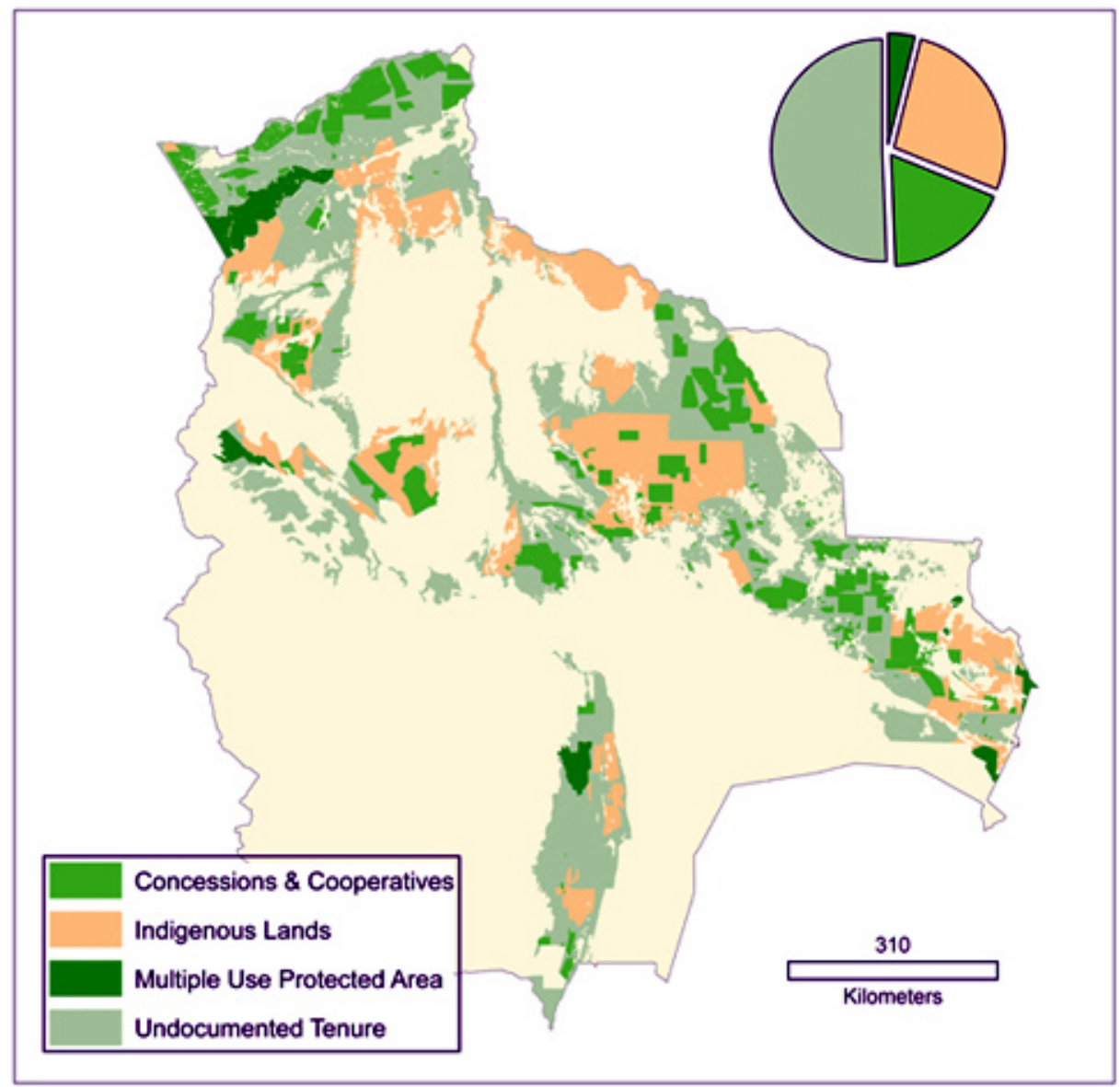

increased within protected areas in the last temporal period (Killeen et al. 2007).

\section{CONCLUSION}

Land-cover change in eastern lowland Bolivia is caused by the implementation of distinct economic production models by various social groups. Differences among the groups are related to their integration into the national economy, degree of mechanization, and access to credit and markets. Cultural differences influence how they establish settlements, whereas their production models determine how quickly and completely the natural habitat is converted to cropland, pasture, or secondgrowth fallow.

The rate of deforestation has increased over time, and the relative contribution of the various social groups to this deforestation has varied according to the market and public policy. Mechanized (i.e., nonindigenous) groups tended to expand their activities when the rates of change associated with nonmechanized (i.e., indigenous) groups were in decline. All groups have been affected by market 
phenomena, including remote communities that rely on forest resources and subsistence agriculture. National urban and international commodity markets are the principal drivers of land-use change for both mechanized farmers and slash-and-burn agriculturalists. Markets stimulate deforestation by increased demand for commodities such as sugar, cotton, and soybean or by causing peasants to migrate when alternative production systems such as rubber and tin decline. Policy initiatives that have accelerated habitat conversion by the various groups include colonization schemes, visa permits for foreigners, infrastructure investment, and land tenure review, as well as the implementation and suspension of programs to eradicate illicit drug crops. An understanding of how various social groups react to market phenomena and policy initiatives is essential to devise effective policies. The Bolivian experience offers important lessons for devising the next round of policies aimed at reducing deforestation.

Responses to this article can be read online at:

http://www.ecologyandsociety.org/voll3/iss 1/art36/responses/

\section{Acknowledgments:}

Financial support for this study was provided to the Friends of the Noel Kempff Mercado Museum Foundation by the Critical Ecosystem Protection Fund, The Nature Conservancy, World Wildlife Fund, and the Vice Ministry for the Environment of the Bolivian government, as well as the Gordon and Betty Moore Foundation via its commitment to Conservation International. The Symposium on Human Demographics and Agriculture on Natural Systems in the Neotropics at the Association of Tropical Biology and Conservation 2007 in Morelia, Mexico, was supported by the national Science Foundation (NSF support \#DEB-0731594).

\section{LITERATURE CITED}

Amemiya, K. 2004. Celebrating Okinawans in Bolivia. Japan Policy Research Institute Critique 11 (4). [online] URL: http://www.jpri.org/publications/ critiques/critique XI 4.html.

Bender, H. S., M. W. Friesen, M. Ediger, I. Hiebert, and M. Gerald. 1987. Bolivia. Global
Anabaptist Mennonite Encyclopedia Online. [online] URL: http://www.gameo.org/encyclopedia/ contents/B665.html.

Bradley, A. V., and A. C. Millington. 2008. Coca and colonists: quantifying and explaining forest clearance under coca and anti-narcotics policy regimes. Ecology and Society 13(1): 31. [online] URL: http://www.ecologyandsociety.org/vol13/iss1/ art31/.

Brookfield, H., and C. Padoch. 1994. Appreciating agrodiversity: a look at the dynamism and diversity of indigenous farming practices. Environment 36(5):8-43.

Bürgi, M., A. M. Hersperger, and N. Schneeberger. 2004. Driving forces of landscape change-current and new directions. Landscape Ecology 19(8):857-868.

Cochrane, T. A., T. J. Killeen, and O. Rosales. 2007. Agua, gas y agroindustria: gestión sostenible de agua para riego agrícola en Santa Cruz, Bolivia. Conservation International Bolivia, La Paz, Bolivia.

Constituyente Soberana. 2006. Conflicto en Yapacaní: colonos toman 500 hectáreas de ganaderos. Constituyente Soberana. [online] URL: http://constituyentesoberana.org/info/?q=yapacanicolonos-inra.

Etter, A., C. McAlpine, D. Pullar, and H. Possingham. 2005. Modeling the age of tropical moist forest fragments in heavily-cleared lowland landscapes of Colombia. Forest Ecology and Management 208(1-3):249-260.

Fearnside, P. M. 2005. Deforestation in Brazilian Amazonia: history, rates, and consequences. Conservation Biology 19(3):680-688.

Hecht, S. B. 2005. Soybeans, development and conservation on the Amazon frontier. Development and Change 36(2):375-404.

Instituto Nacional de Reforma Agraria. 2007a. Guía para la verificación de la función social y de de la función económico social. Instituto Nacional de Reforma Agraria, Ministerio de Desarrollo Agropecuaro y Medio Ambiente, Gobierno de Bolivia, La Paz, Bolivia.

Instituto Nacional de Reforma Agraria. $2007 b$. Saneamiento integrado al catastro legal, tierras 
comunitarias de origen (TCOs). Instituto Nacional de Reforma Agraria, Ministerio de Desarrollo Agropecuaro y Medio Ambiente, Gobierno de Bolivia, La Paz, Bolivia.

Killeen, T. J. 2007. A perfect storm in the Amazon wilderness, development and conservation in the context of the Initiative for Integration of the Regional Infrastructure of South America (IIRSA). Advances in Applied Biodiversity Science 7:4-99. Available online at: http://www.bioone.org/perlserv/? request=get-document $\&$ doi $=10.1896 \%$ 2F978-1-934151-07-5.4.

Killeen, T. J., V. Calderon, L. Soria, B. Quezada, M. K. Steininger, G. Harper, L.A. Solórzano, and C. J. Tucker. 2007. Thirty years of land-cover change in Bolivia. Ambio 36(7):600-606.

Killeen, T. J., T. M. Siles, L. Soria, and L. Correa. 2005. La estratificación de vegetación y el cambio de uso de suelo en Las Yungas y El Alto Beni de La Paz. Ecología en Bolivia 40(3):32-69. Available online at: http://editorenjefe.ecologiabolivia.googlepages. com/indice40(3).

Klein, H. S. 1992. Bolivia, the evolution of a multiethnic society. Second edition. Oxford University Press, New York, New York, USA.

Kometter, R. F., M. Martinez, A. G. Blundell, R. E. Gullison, M. K. Steininger, and R. E. Rice. 2004. Impacts of unsustainable mahogany logging in Bolivia and Peru. Ecology and Society 9(1): 12. [online] URL: http://www.ecologyandsociety.org/vol9/ iss1/art12/.

Laurance, W. F., T. E. Lovejoy, H. L. Vasconcelos, E. M. Bruna, R. K. Didham, P. C. Stouffer, C. Gascon, R. O. Bierregaard, S. G. Laurance, and E.Sampaio. 2002. Ecosystem decay of Amazonian forest fragments: a 22-year investigation. Conservation Biology 16(3):605-618.

Machado, R. B., M. B. R. Neto, J. M. C. Silva, and R. B. Cavalcanti. 2007. Cerrado deforestation and its effects on biodiversity conservation. Advances in Applied Biodiversity Science $\mathbf{8}$ in press.

Margulis, S. 2004. Causes of deforestation of the Brazilian Amazon. World Bank, Washington, D.C., USA.
Morton, D. C., R. S. DeFries, Y. E. Shimabukuro, L. O. Anderson, E. Arai, F. del Bon EspiritoSanto, R. Freitas, and J. Morisette. 2006. Cropland expansion changes deforestation dynamics in the southern Brazilian Amazon. Proceedings of the National Academy of Sciences 103 (39):14637-14641.

Movimiento al Socialismo. 2007. Programa de gobierno MAS-IPSP. Bolivia digna, soberana y productiva para vivir bien. Título I: diagnóstico. Movimiento al Socialismo, La Paz, Bolivia. Available online at: http://www.masbolivia.org/mas/ programa/programa05.htm.

Myers, N., R. A. Mittermeier, C. G. Mittermeier, G. A. B. da Fonseca, and J. Kent. 2000. Biodiversity hotspots for conservation priorities. Nature 403(6772):853-858.

Pacheco, P. 2006. Agricultural expansion and deforestation in lowland Bolivia: the import substitution versus the structural adjustment model. Land Use Policy 23(3):205-225.

Paterson, R. T. 1984. Investigación y desarrollo de pastos tropicales, Santa Cruz: informe final de la asignación técnica de la MBAT en el Programa de Pasturas del CIAT 1976-1984. Missión Británica en Agricultura Tropical, Santa Cruz, Bolivia.

Peña-Claros, M., and P. Zuidema. 2000. Limitaciones demográficas para el aprovechamiento sostenible de Euterpe precatoria para producción de palmito: resultados de dos estudios en Bolivia. Ecología en Bolivia 33:3-21.

Prefectura del Departamento y Consorcio IPCES-KWC. 1996. Memoria del PLUS. Plan de uso del suelo del Departamento de Santa Cruz, Bolivia. Prefectura del Departamento y Consorcio IP-CESKWC, Santa Cruz, Bolivia.

Putz, F. E., M. A. Pinard, T. S. Fredericksen, and M. Peña-Claros. 2004. Forest science and the BOLFOR experience: lessons learned about natural forest management in Bolivia. Pages 64-96 in D. J. Zarin, J. R. R. Alavalapati, F. E. Putz, and M. Schmink, editors. Working forests in the Neotropics: conservation through sustainable management? Columbia University Press, New York, New York, USA. 
Ruiz, S. A. 2005. Rentismo, conflictos y bosques en el norte amazónico boliviano. Center for International Forestry Research, Bogor, Indonesia.

Sierra, R. 2000. Dynamics and patterns of deforestation in the western Amazon: the Napo deforestation front, 1986-1996. Applied Geography 20(1):1-16.

Skole, D. L., and C. J. Tucker. 1993. Tropical deforestation and habitat fragmentation in the Amazon: satellite data from 1978 to 1988 . Science 260:1905-1910.

Stearman, A. M. 1985. Camba and Kolla: migration and development in Santa Cruz, Bolivia. University of Central Florida Press, Orlando, Florida, USA.

Steininger, M. K. 2000. Satellite estimation of tropical secondary forest above-ground biomass: data from Brazil and Bolivia. International Journal of Remote Sensing 21(6-7):1139-1157.

Steininger, M. K., C. J. Tucker, J. R. G. Townshend, T. J. Killeen, A. Desch, V. Bell, and P. Ersts. 2001. Tropical deforestation in the Bolivian Amazon. Environmental Conservation 28 (2):127-234.

Tucker, C. J., D. M. Grant, and J. D. Dykstra. 2004. NASA's global orthorectified Landsat data set. Photogrammetric Engineering and Remote Sensing 70(3):313-322.

United Nations Office on Drugs and Crime. 2007. Coca cultivation in the Andean region for 2006: a survey of Bolivia, Colombia, Ecuador and Peru. United Nations Office on Drugs and Crime, Vienna, Austria. Available online at: http://www.unodc.org/ unodc/en/publications.html.

World Bank. 1997. Eastern lowlands natural resource management and agricultural production project. Project ID: P006152. World Bank Project database. [online] URL: http://web.worldbank.org/ external/projects/main?pagePK=64283627\&piPK= 64290415\& theSitePK $=40941 \&$ menuPK $=228424 \&$ Projectid=P006152. 
Appendix 1. Google Earth KMZ file with links to geographic marers and descriptions of the social groups included in this study.

Please click here to download file 'appendixl.kmz'. 
Appendix 2. Overview of social groups linked to the Google Earth KMZ file (Appendix 1).

\section{LOWLAND INDIGENOUS COMMUNITIES}

Multiple different ethnic groups have inhabited the lowland regions of Bolivia for centuries, including: Guaraní, Chiquitano, Guarayo, Sirionó, Moxeño, Tsimán, Tacana, Araona, Chacóbo, Esse Ejé, Ayoreodé, and others; groups occupy lands from the humid Amazon to the seasonally dry Gran Chaco. Most are subsistence agriculturalists and supplement their diet with resources harvested from the surrounding forests or aquatic systems (see link to Forest Products Sector). Land is held jointly by communities; families occupy plots according to need and social rank, but garden plots rarely exceed two hectares. Communities are recognized in satellite images by the presence of clusters of small patch deforestation surrounded by second growth forest; settlements are usually located along rivers or other bodies of water. Collateral information was derived from cartographic coverage of population centers provided by the Bolivian census and personal knowledge of the country by the authors.

\section{Lowland Indigenous Communities - Urubichá}

The Guarayo Community in northern Santa Cruz is on the edge of the agricultural frontier, where subsistence indigenous farmers live in juxtaposition with extensive and intensive cattle ranchers. This region is experiencing change due to the expansion of the agriculture frontier and competition for land by Agro Industrial Corporations and Andean Indigenous Colonists

\section{Lowland Indigenous Communities - Manipuri}

Scattered forest settlements are situated along the Rio Manipuri, a tributary of the Madre de Dios River; resident families practice subsistence agriculture in combination with fishing and hunting; most also participate in the seasonal harvest of Brazil nuts.

\section{Lowland Indigenous Communities - Riberalta}

The town of Riberalta is surrounded by Lowland Indigenous Communities from the Tacana and Chacóbo ethnic groups. Deforestation rates peaked in the late 1980s as migration increased as rubber tapers were forced to abandon remote stations following the decision by Brazil to end subsidies for Amazonian rubber. Deforestation rates are increasing again after showing a decline in the 1990s.

\section{Lowland Indigenous Communities - San Ignacio de Velasco}

The provincial capital of San Ignacio de Velasco is surrounded by numerous Chiquitano villages. Land title is held by the community and families practice subsistence agriculture using slash and burn; the abundance of second growth forest is the result of their use of a rotational fallow to manage soil fertility and weeds. The region has a natural mosaic of forest and savanna.

\section{ANDEAN INDIGENOUS COLONISTS}

Migration of Aymara and Quechua speaking people from the Andean highlands to the lowlands began in the late 1950s and early 1960s with the construction of highways that linked the lowlands with the Bolivian Altiplano. There are four major areas of settlement each with unique climatic and soil characteristics that influence the selection of agricultural production systems. Title for 50 hectares properties are ceded to individual families that are organized in syndicates to facilitate the colonization and land titling processes. Slash and burn agriculture predominates and a large portion of land is in fallow; mechanization and land consolidation has increased in regions that grow crops for national markets. Areas colonized by Andean Indigenous Colonists can be identified in satellite images by the pattern of densely clustered, small $(<10 \mathrm{ha})$, irregularly shaped deforestation patches on landscapes with abundant secondary forest.

\section{Andean Indigenous Colonists - San Julian}

San Julian is one of four major colonization zones; it was established between 1976 and 1984. It is laid out on a rectangular grid of roads; at each intersection is a village or "Nucleo". Each nucleo is composed 
of 50 hectare land-holdings that extend outward from the village square to create the radial land-use pattern which identifies this as a planned colonization zone. The older "nucleos" closer to the main highway (East) have become mechanized, as evidenced by the brighter reflectance from bare soil; in contrast the younger and more remote "nucleos" with an abundance of second growth vegetation (bright green in the Landsat Image) characteristic of the slash and burn agricultural model.

\section{Andean Indigenous Colonist - Chapare}

This area was settled in the 1960s following the construction of a modern highway linking the Chapare with the city of Cochabamba. Very high rainfall regimes $(>6000 \mathrm{~mm}$ ) limit the potential for mechanized agriculture. The major crops are coca, and a variety of fruits such as citrus, pineapple and banana; the landscape has an abundance of second growth forest indicative of the slash and burn technology.

\section{Andean Indigenous Colonists - Alto Beni}

This broad synclinal valley in the Andean foothills has received tens of thousands of immigrants since settlement began in the 1960s. The area has a diversified agricultural economy that includes staples such as rice and corn for local consumption and a variety of fruits that it produces for the city of La Paz, as well as coffee, cacao, and tea for export.

\section{Andean Indigenous Colonists - Yapacaní}

The area was colonized by immigrants from the Andean highlands in the 1960s. The major crops are rice, which is largely produced by manual labor; production is limited by very high rainfall regimes, as well as lack of technology and access to capital. Slash and burn agriculture and rotational fallow have led to an extensive deforestation and low intensity land-use. The forested mountains in the background are part of Amboró National Park

\section{YUNGUEÑO INDIGENOUS FARMERS}

Aymara and Quechua communities have occupied the humid tropical valleys on the eastern slope of the Andes (known as the Yungas) for centuries. Yungueño Indigenous Farmers maintain close commercial and cultural ties with highland communities and urban centers; production systems are based on perennial crops, such as citrus, coffee and coca. Land is held by families and properties are seldom larger than a few dozen hectares.

\section{Yungueño Indigenous Farmers - La Paz}

Aymara communities have occupied the humid tropical valleys on the eastern slope of the Andes (known as the Yungas) for centuries. Yungueño Farmers are the major producers of legal coca leaf for national markets recurrent fire has prevented large parts of previously deforested landscapes to regenerate as second growth forest and species poor grasslands are widespread.

\section{Yungueño Farmers - Cochabamba}

The humid valleys near Cochabamba have been farmed for decades, if not longer, by Quechua indigenous communities that commercialize their production in the city of Cochabamba.

\section{CRUCEÑO FARMERS}

Farmers with a European heritage have cultivated land or raised cattle near the lowland city of Santa Cruz de la Sierra since its establishment in the 16th Century. This region has been the center of Bolivia's recurrent booms in mechanized agriculture, starting with cattle, rice, and sugar cane in the 1960s, which was diversified by cotton in the 1970s and soy in the 1990s. Family farms are the predominant form of land tenure, with property size varying from tens to more than a thousand hectares. The region has relatively fertile alluvial soils and plentiful but not over abundant rains $(1000-1800 \mathrm{~mm})$ that makes it the most important agricultural region in the country. Agricultural production is linked to urban markets and is part of a value added production chain that incorporates both pre and post harvest components.

\section{Cruceño Farmers - Río Grande}

The last lands to be cleared were those adjacent to the Río Grande, which periodically floods surrounding fields. 


\section{Traditional Farmers - Tarija}

The small farmers in the Chaco region of Tarija are similar in culture and production systems as the much larger group in Santa Cruz

\section{Cruceño Farmers - Mineros}

The Alluvial Plan situated between the Río Piraí and the Río Grande is the center of the Santa Cruz diversified production system that includes both large and small farmers. Sugar cane is an important crop and Mineros has a large sugar mill. Other important crops are soy, rice, and cotton.

\section{Cruceño Farmers - Montero}

Poor soil management practices in the 1970s led to soil compaction and many of the lands that were originally cleared for row crops are now used as grazing lands. Recently, land owners have been recovering lands by using sub-soil plows to alleviate the soil compaction and recover these lands for agriculture

\section{JAPANESE COLONISTS}

Japanese immigrants first came to Santa Cruz, Bolivia in the mid 1950s. Family farms have a diversified production system that includes crop rotation, minimum tillage, and livestock grazing. Properties range between 250 and 500 hectares and can be identified in satellite images by rectangular or square shapes. The colonies are situated on rich alluvial soils and enjoy precipitation conducive to double cropping; farmers have formed cooperatives to obtain credit, seek technical assistance, purchase supplies, and commercialize production.

\section{Japanese Colonists - Yapacaní}

The colony of San Juan de Yapacaní was established by immigrants from Nagasaki in the late 1950s. The degree of mechanization and land-use intensity is a stark contrast to the Andean Indigenous Colonists situated to the west of the Río Yapacaní.

The Japanese are considered by some to be Bolivia's most successful farmers, as evidenced by this area which has been under cultivation for almost 50 years. Major crops are rice, citrus and soy; as well as raising poultry and cattle.

\section{Japanese Colonists - Okinawa}

These medium size farms on the West Bank of the Río Grande are situated on some of the best soils in Bolivia in an area with low climate risk. Japanese farmers have led technological innovation including soy and irrigation.

\section{MENNONITE COLONIES}

These small farmers first came to Bolivia in the late 1960s from Mennonite communities in Paraguay, Canada and Mexico. Colonies are formed by families that pool resources to purchase and subdivide a single large landholding; family farms are small, averaging between about 100 and 150 hectares. Mennonites practice a form of agriculture based on religious beliefs that prescribe the use of selected technologies; in Bolivia, most own tractors and farm implements while eschewing the use of rubber tires, trucks and automobiles. Mennonites cultivate cash crops such as soy, sorghum, sesame and cotton; they use chemical inputs and genetically modified organisms, but have been slow to adapt minimum tillage. Mennonite colonies are situated on the alluvial plain situated to the east of the Río Grande or on the piedmont south of the city Santa Cruz de la Sierra, -- areas characterized by low precipitation and prolonged dry season. Their communities can easily be identified in satellite images because homesteads are established along a single secondary road with narrow parallel fields that extend from the homesteads

\section{Mennonite Colonists - Los Troncos}

Older Colonies are notable by the complete conversion of all natural habitat and the high intensity of land-use with almost 100 percent dedicated to raw crops. 


\section{Mennonite Colonists - Southern Expansion Zone}

This colony is established in the Southern sector of the Alluvial Plain of the Eastern Expansion Zone where climate risk is highest.

\section{Mennonite Colonists - Piedmont}

The large colony situated south of Santa Cruz and west of the Río Grande is one of the oldest colonies in Bolivia

\section{Mennonite Colonists - Parapetí}

The communities 1on the Andean Piedmont is in an area of high climate risk and sandy soils

\section{New Mennonite Colony - San Jose}

This is a new Mennonite Colony established after 2004 (post analysis). Farm houses are situated along a road that unites the colony, with each family farming a strip of land is situated behind the homestead.

\section{Older Mennonite Colony near San Jose}

This is one of the older Mennonite colonies, which was established between 1976 and 1984. The Mennonites did not yet understand the sols and climate of Bolivia and this colony is established on the edge of the Brazilian Shield with poor soils and a strong dry season. The properties to the north of the colony and those situated to the west of the highway are Intensive Cattle Ranchers.

\section{AGRO INDUSTRIAL CORPORATIONS}

Local businessmen and foreign investors have brought technological expertise from Brazil and the United States. Soy processing facilities are owned and operated by multinational corporations, as well as regional companies from Colombia, Peru, and Bolivia.

\section{Agro Industrial Corporations - Eastern Expansion Zone}

The alluvial plain situated east of the Río Grande is dominated by large-scale farms that grow soy and other crops for national and international markets. Most have maintained strips of native vegetation as wind breaks, which were a condition of the loans made in the early 1990s, as part of the "Eastern Lowlands Project" of the World Bank. Many farms were still being established or expanding when this Landsat image was taken in 1999 or 2000. The Landscape is shared with Mennonite Colonies that are much more intensely farmed and which lack wind breaks.

\section{Agro Industrial Corporation - Northern Expansion Zone}

The northern sector is more humid than the eastern sector and can grow soy during both the summer and winter cycles; nonetheless, farms rotate with other crops, particularly maize, to control pests. Expansion in the Northern Expansion Zone is constrained by seasonal flooding. The landscape south of the agroindustrial zone is dominated by the smaller properties of Cruceño Farmers

\section{INTENSIVE CATTLE RANCHERS}

Cultivated pastures have a much higher carrying capacity when compared to native grassland this allows higher stocking rates, improved animal husbandry, and the introduction of genetically improved breeds. Properties range from a few hundred to more than 50,000 hectares. Intensive Cattle Ranches occurs in areas where mechanized agriculture is not feasible because it is too dry hilly or the landscape to hilly; consequently, land clearing is solely dedicated to pasture establishment. Most of the investment capital comes from urban centers, particularly Santa Cruz de la Sierra; however, Brazilians investors have been attracted by the low land prices and the strong value of the Brazilian currency.

\section{Intensive Cattle Ranchers - El Carmen}

Originally pastures were established on deforested lands as a means to compliment native grasses; but in recent years, ranchers have been converting Cerrado savannas and scrubland as a means to improve productivity. 


\section{Intensive Cattle Ranchers - Gran Chaco}

It is too dry for mechanized agriculture in the Gran Chaco region, thus most land clearing in this part of the alluvial plain of the Río Grande is for pasture establishment. Ironically, this intensive cattle model using cultivated grasses is replacing an extensive cattle model based on native shrubs and trees as forage. Efforts to use centre pivot irrigation systems (circular patterns) have not been economically viable due to the cost of fuel.

\section{Intensive Cattle Ranchers - Cobija}

The intensive cattle production model that is widespread in Acre, Brazil is being implemented near Cobija the capital of the Department of the Pando, a region known for its high forest and production of Brazil nuts (known as Amazon nuts in Bolivia).

\section{Intensive Cattle Ranchers - San Javier}

The town of San Javier has a long tradition of raising beef cattle on the native grasslands situated south of the village, which was established by the Jesuits in the 17th Century. However, the construction of a cheese factory in the 1970s and the introduction of cultivated grasses led to the development of a more intensive cattle raising model.

\section{EXTENSIVE CATTLE RANCHERS}

Cattle ranches that rely on the forage resources of native vegetation remain one of the most important agricultural production systems in eastern Bolivia and include large estancias owned by corporations and individuals, both domestic and foreign, as well as small family farms. Stocking rates are low and animal husbandry is rudimentary; habitat conversion in recent years has come from land holders shifting to cultivated pastures to improve productivity.

\section{Extensive Cattle Ranchers - Rogagaua}

The Llanos de Moxos are a mosaic of savanna, wetland and forest. The traditional cattle ranching model has been effective in producing beef based on native habitat. The habitat diversity on these landscapes reflects differences in water chemistry, inundation regime, fire frequency, and grazing intensity.

\section{Extensive Cattle Ranchers - Chiquitania}

The native savannas on the Precambrian Shield in Bolivia (known as Chiquitania) have been used for centuries as forage for raising cattle

\section{Extensive Cattle Ranchers - Beni}

The native grasses of the vast seasonally inundated savannas of the Llanos de Moxos have been the mainstay of Bolivia's beef cattle production system for centuries. The Beni continues to be the largest producer of beef cattle in the country, in spite of the growth of the intensive production model; many of the calves raised in the Beni are sold to Intensive Cattle Ranchers in Santa Cruz

\section{Extensive Cattle Ranchers - Gran Chaco}

The traditional beef cattle production model in the semi-arid Gran Chaco is based on the native shrubs and trees that cattle browse for forage. Each of the small deforestation patches is a cattle ranch station; production is limited by a lack of both water and forage, causing cows to loose weight during the dry season.

\section{FOREST PRODUCTS SECTOR}

This category of economic actor includes businesses, cooperatives, and indigenous communities that depend on forest resources for the raw materials that supply their production systems. This may seem an unlikely combination, as the two principal subgroups are private companies with long-term concessions on state lands and indigenous groups that hold title to forest reserves; however, both groups share the common habit of using forest resources. This includes mainly timber, but also Brazil nut, rubber, palm hearts, and palm thatch, as well as wildlife and fish resources. Geographically, the Forest Products Sector spans all of eastern Bolivia, including the humid forests of the Southwest Amazon, the montane forests of the eastern slope of the Andes, and the seasonally dry forests of Chiquitania. 


\section{Forest Products Sector - Pando}

The Pando has long been the center of Bolivia's non-timber forest product sector, principally rubber and Brazil nuts. Timber only became important in the late 1990s when Mahogany was extirpated from the rest of Bolivia's forests. Today's timber sector is expanding the use of other tropical species.

\section{Forest Products Sector - Manuripi}

The Manuripi - Heath Biological Reserve is a multiple use area, where forest conservation and management are both priorities.

\section{Forest Products Sector - Bosque Chimanes}

The Chimanes Forest Reserve is shared by commercial companies with long-term concessions and indigenous communities that have been deeded land as communal reserves. Both groups hope to sustainably manage the reserve for timber extraction.

Logging roads and timber mills established in the 1980s are visible in this Landsat image taken in 1999 or 2000 .

\section{Forest Products Sector - Mamoré}

The Mamoré River is a forest corridor that transects the Llanos de Moxos; its wetland habitats provide essential ecosystem and economic services that support the domestic fishing industry, while the river itself is a key transportation link.

\section{Forest Products Sector - Baures}

Logging roads are usually the first step in the settlement process. This could well be the next major deforestation front in Bolivia.

\section{Forest Products Sector - Bajo Paragua}

The Bajo Paragauá Forest Reserve is managed by private companies that have long-term concessions to state lands. The Bolivian government has announced plans to settle 5000 Andean Indigenous Colonists into this region.

\section{Forest Product Sector - Chiquitania}

The Chiquitano dry forest contains perhaps of the world's largest reserve of extremely hard-wooded timber species. This locality is within a commercial logging concession that pays royalties to the state for the exploitation of timber.

\section{Forest Products Sector -Pantanal Region}

The seasonal forests of the Pantanal region are threatened over the short-term by the exploitation of vegetable charcoal to supply pig iron factories in Brazil. Land-holders are clearing land, making charcoal, and - simultaneously - establishing Intensive Cattle Ranches.

\section{Forest Products Sector -Southern Andes}

The front ranges of the Andes between Santa Cruz and the Argentine Border are a mix of multiple use national and regional protected areas, indigenous reserves, forest concessions and private properties. Forest habitat varies from deciduous to cloud forest depending on altitude and apsect.

\section{RESTRICTED USE ZONE}

This category includes national protected areas that enjoy complete protection and e forest exploitation is strictly prohibited; in most cases, the area is uninhabited.

\section{Restrict Use Zone - Kaa-Iya del Gran Chaco}

Bolivia's largest protected area is co-managed by the Guaraní communities. The linear feature in the Northern sector of the Park is the Bolivian - Brazil Gas Pipeline; an endowment to finance park management was created as part of the environmental management plan that accompanied its construction in the late 1990s. 


\section{Restricted Use Zone - Madidi}

Two national parks (Madidi and Apolobamba) extend from lowland forests on the piedmont to the snow capped peaks of the Cordillera of Apolobamba. They are situated next to the Tambopata / Bahuaha Sonené protected area complex in Peru, creating a protected area complex of global importance.

\section{Restricted Use Zone - Carrasco}

The montane cloud forests of Carrasco National Park are situated adjacent to the Chapare colonization zone.

\section{Restricted Use Zone - Amboró}

Amboró has been zoned to distinguish between strict protection (National Park) and multiple use areas (Integrated Natural Management Area). The cloud forests are situated on the front ranges behind the piedmont, where Andean Indigenous Colonists have settled, and intergrades' with semi-arid montane habitats where irrigation agriculture is predominant.

\section{Restricted Use Zone - Noel Kempff}

Noel Kempff Mercado National Park is an IUCN Category II protected area, where the extraction of natural resources, such as timber and wildlife, is strictly forbidden, except for traditional use by indigenous communities.

\section{URBAN AREAS}

\section{Urban Areas - Santa Cruz de la Sierra}

The urban economy is intimately linked to agricultural production, both in the pre- and post- harvest components. Santa Cruz has experienced consistent growth over four decades, from a small town of 70,000 inhabitants in the late 1960s to almost 1.5 million in 2005. This growth has left its mark on urban planning via the highway rings for which the city is known. 